\title{
First Record of West Nile Virus Specific Seroconversion in Dogs From Eastern Romania
}

\author{
Alexandra Luciana CRIVEI ${ }^{1 *}$, Ioana RĂȚOI (ANTON) ${ }^{1}$, Cristian RĂILEANU ${ }^{1}$, Daniela POREA ${ }^{1}$, Dragoş \\ ANIȚA $^{1}$, Gheorghe SAVUȚA ${ }^{1}$, Luanda OȘLOBANU ${ }^{1}$ \\ ${ }^{1}$ Department of Public Health. The University of Agricultural Sciences and Veterinary Medicine Iaşi, \\ România \\ *corresponding author: alexandra.luciana05@yahoo.com
}

Bulletin UASVM Veterinary Medicine 75(2)/2018

Print ISSN 1843-5270; Electronic ISSN 1843-5378

doi:10.15835/buasvmcn-vm:2017.0060

\begin{abstract}
:
West Nile virus (WNV) infection causes diseases that vary in intensity from asymptomatic to fatal encephalitis in humans and animals. The etiological agent is a Flavivirus belonging to Japanesse Encephalitis complex. This zoonotic virus is maintained in nature in an enzootic cycle between mosquitoes and birds as amplifying hosts. Except birds, a wide variety of animals develop seroconversion caused by infection, and previous studies indicated that dogs may be considered as sentinel for WNV. The importance of studying this virus is caused by its zoonotic character, limited possibilities of active surveillance and real-time alertness of the infection's presence in the human and animal populations. The aim of the study was to demonstrate and estimate the seroconversion in dogs within an area with confirmed cases in humans and animals. A total number of 76 serum samples were evaluated for the presence of specific anti WNV antibodies using a commercial competitive ELISA kit, for the detection of anti-pr-E antibodies (ID Screen ${ }^{\circledR}$ West Nile Competition Multi-species). The results indicated specific antibodies in $32(42.1 \%)$ out of 76 samples tested. Positive results were recorded in all four counties from which samples were collected. Our preliminary results proved the circulation of WNV in dogs in areas where the infection was previously reported in animals and humans.
\end{abstract}

Keywords: anti WNV Ig G, competition ELISA, dogs, serosurvey, West Nile Virus

\section{Introduction}

The infection with West Nile virus (WNV) is caused by a mosquito-borne Flavivirus, belonging to the Japanese encephalitis antigenic complex (Garcia-Bocanegra et al., 2012). WNV is a positivestrand RNA virus (Briese and Bernard, 2005) and nowadays it is known as the most widespread flavivirus (Gamino and Hòfle, 2013). This viral pathogen represents a global importance concerning public and animal health. The virus was first isolated in the West Nile district of Uganda, in 1937, from a woman with a febrile process (Hubálek and Halouzka, 1999). WNV transmission cycle involves the rural and urban areas, where the pathogen affects birds, horses, humans and also other mammals (Paz, 2015). The natural cycle of WNV infection involves migratory birds and ornitophilic mosquitoes, mainly Culex spp. and Aedes spp. In this cycle, birds act as amplifying hosts, due to their high level of viremia. In addition, migratory birds are instrumental in the introduction of virus to temperate areas. Horses, humans and other mammalians are deadend hosts because they develop a low level of viremia (Briese and Bernard, 2005).

In Romania, the first major outbreak in humans, was confirmed in July - October, 1996, when over 393 cases were serologically confirmed, in Bucharest and in other south-eastern regions of the country (Calistri et al., 2010).

Regarding infection in dogs, it has not been thought to be important in the epidemiology 
of WNV, but it is known that dogs can be experimentally susceptible to infection, developing myopatic signs and low-grade-viremia (Buckweitz et al., 2003).

To our knowledge, considering dogs as sentinels for the WNV, no previous research has been done before in our country. Thus, the aim of this study was to identify the possible virus circulation in dog populations and to assess the seroconversion in samples collected from four counties within Romania.

\section{Materials and methods}

During 2012-2014, 76 blood samples were collected from dogs, randomly chosen, disregarding health status or age. The samples were collected from four counties (Bacau, Suceava, Tulcea and Iasi), situated in Eastern region of Romania. The sampling areas have been chosen due to the human infections (CNSCBT, 2012), birds (Ludu et al., 2010) and horses (Ludu et al., 2014) WNV seroprevalence signaled before. The settlement of Tulcea County, located near the Danube Delta with vast areas of wetlands and a high density of competent vectors, has a special importance since this area, is situated in the routes of many migratory birds.

The dog's potential exposure to mosquitoes is related to the poor hygiene and high density of animals within shelters and also to the fact that animals are let to roam near households. Also, the spatial distribution of the virus is in line with the European Mosquito Bulletin, according to which, the main vectors of the WNV are distributed along the south, southeast, north and central sides of the country.

The blood samples were collected from dogs in paddocks $(n=46)$ and from household dogs $(n=30)$, then processed by centrifugation for 10 minutes at $2000 \mathrm{x}$ g for serum separation and stored at $-20^{\circ} \mathrm{C}$ until use.

Serological screening of dog sera was performed using a commercial competitive ELISA kit for detection of anti-pr-E antibodies (ID.VET Innovate Diagnostics). The assays were performed and interpreted according to manufacturer's instructions. Serum samples were considered positive if the threshold value for optical density at $450 \mathrm{~nm}(\mathrm{~S} / \mathrm{N})$ was $<40 \%$, as recommended by the manufacturer.

\section{Results and discussions}

Seropositive dogs were found in all counties taken under study, antibodies to WNV being detected in 32 out of 76 samples, showing an overall seroprevalence rate of $42,1 \%$ with a $95 \%$ confidence interval (CIs) [0,31-0,53].

Data were analysed using the SPSS IBM vs 17 for Windows statistical software package. Odds ratios and 95\% (CIs) confidence intervals were calculated in the logistic regression model. A $P$ values $<-0.05$ was considered to be statistically significant.

Dog's seroprevalence was compared between counties. The highest seroprevalence rate observed in dogs, was recorded in Bacău County. Out of 24 samples collected from paddocks and private households, 16 were positive for WNV antibodies (66,7\%) CIs (95\%) [0,46-0,87] (Tab.1.). In Iaşi County, where infection with WNV was confirmed in horses in 2011 (Ludu et al., 2014), in humans in 2012, 2013 and 2014 (CNSCBT 2012, $2013,2014)$, the seroprevalence in dogs was $30 \%$ CIs $[0,08-0,42]$, meaning that, out of 30 collected samples, nine were positive for WNV antibodies. The second highest seroprevalence rate $(60 \%)$ CIs $(95 \%)[0,23-0,96]$, was observed in Tulcea County, where out of ten tested dogs, six had anti-WNV antibodies. In Suceava County, where the infection with WNV was confirmed in horses in 2007 (Ludu et al., 2014), anti-WNV antibodies were detected only in one sample, and the other 11 were clearly negative (8,3\%) CIs (95\%) [-0,1-0,26].

The serological results reported in this study indicates that $42,1 \%$ of tested dogs were infected with WNV, showing a wide geographical distribution of this flavivirus among the collecting areas.

Notable differences in rates could be observed in Tulcea and Suceva County. The differences occur due to geographic area and ecosystems. Tulcea County has a high density of residential and migratory birds, competent vectors, and also a high amount of wetlands.

In contrast, the climatic conditions in Suceava County and the ecosystem are not favorable to virus circulation, therefore the dogs have a lower level of exposure to mosquito's bites.

The odds of seropositivity were more than three times $(3,3)$ higher for households $(73,3 \%)$ than for shelter dogs $(21,7 \%)$, with a 95\% confidence interval (CIs) $[0,56-0,90]$ both for dogs 
Tab. 1. Number of tested samples for the detection of WNV anti-pr-E antibodies by Competitive ELISA

\begin{tabular}{ccc}
\hline No. & County & Tested samples \\
\hline 1. & Bacău & 24 \\
\hline 2. & Iași & 30 \\
\hline 3. & Tulcea & 10 \\
\hline 4. & Suceava & 12 \\
\hline \multicolumn{2}{c}{ Total } & 76 \\
\hline
\end{tabular}

Tab. 2. Prevalence of West Nile virus antibodies in dog populations from the East side of România 2012-2014

\begin{tabular}{ccccc}
\hline & & \multicolumn{3}{c}{ Ig G-positive samples } \\
\hline County & Tested samples & No. & $\%$ & $(95 \% \mathrm{CI})$ \\
\hline Bacău & 24 & 16 & $66,7 \%$ & {$[0,31-0,53]$} \\
\hline Iași & 30 & 9 & $30 \%$ & {$[0,13-0,46]$} \\
\hline Tulcea & 10 & 6 & $60 \%$ & {$[0,29-0,90]$} \\
\hline Suceava & 12 & 1 & $8,3 \%$ & {$[-0,07-0,23]$} \\
\hline Total & 76 & 32 & $42,1 \%$ & {$[0,31-0,53]$} \\
\hline
\end{tabular}

from households and for shelter dogs $95 \%$ CIs [0,09-0,34].

The highest proportion of seropositive dogs was detected in private households from Bacău County, and considering the proximity to human settlements, they could attract the infected mosquitoes and reduce the human infection (Davoust et al., 2014).

The seroprevalence rate obtained from shelter dogs in Iasi (30\%), might be caused by intensive mosquito biting activity, the density of animals within paddocks and also because of the poor hygiene (Ozkul et al., 2006), all these contributing to virus spreading.

In this preliminary study, the overall percentage of WNV seropositivity in dogs was lower than the seroprevalence recorded by Levy et al. $(55,9 \%)$ in 2011.

The seroprevalence recorded in our study was almost twice higher compared to seroprevalence highlighted by Gaunt et al. (2017) in Canada (28\%), and the one obtained by Kile et al. (26\%) in 2005 . Serological studies conducted by other authors, showed lower percentage of WNV seroprevalence compared to our surveillance: $37 \%$ by Ozkul et al. (2006) in Turkey, 8,4\% by Maquart et al. (2017) in Corsica, France, 4,8 \% by Garcia-Bocanegra et al. (2018) in Spain, 4,6 \% by Lan et al. (2011) in China, and 2,36\% by Buckweitz et al. (2003) in Cloumbia.

By correlating the collection time of dog samples and the evolution of human infection with West Nile virus at the same time, we can state that there is a virus persistence in the south and southeast of the country, known as endemic. Thus, of the 30 dog samples collected in Iasi, nine were positive, while the evolution of human cases during 2012-2014 in Iasi, has constantly evolved. In 2012 one case of infection with WNV was confirmed, in 2013 two cases and in the 2014 another case was confirmed (CNSCBT 2012, 2013, 2014). In Bacau County, although there were many positive samples in dogs (16 out of 24 collected), infection with West Nile virus was detected in humans only in 2013 (CNSCBT 2012, 2013, 2014).

In Tulcea County, seroconversion in dogs had the highest percentage, although the samples were few (six of ten collected samples were positive). The evolution of human infection Tulcea County in 2013 shows that out of 22 confirmed cases, two were recorded in this area (CNSCBT 2013). The only county were there was no human cases within the studied period, was Suceava County. The lack of immunological response is also reflected in 


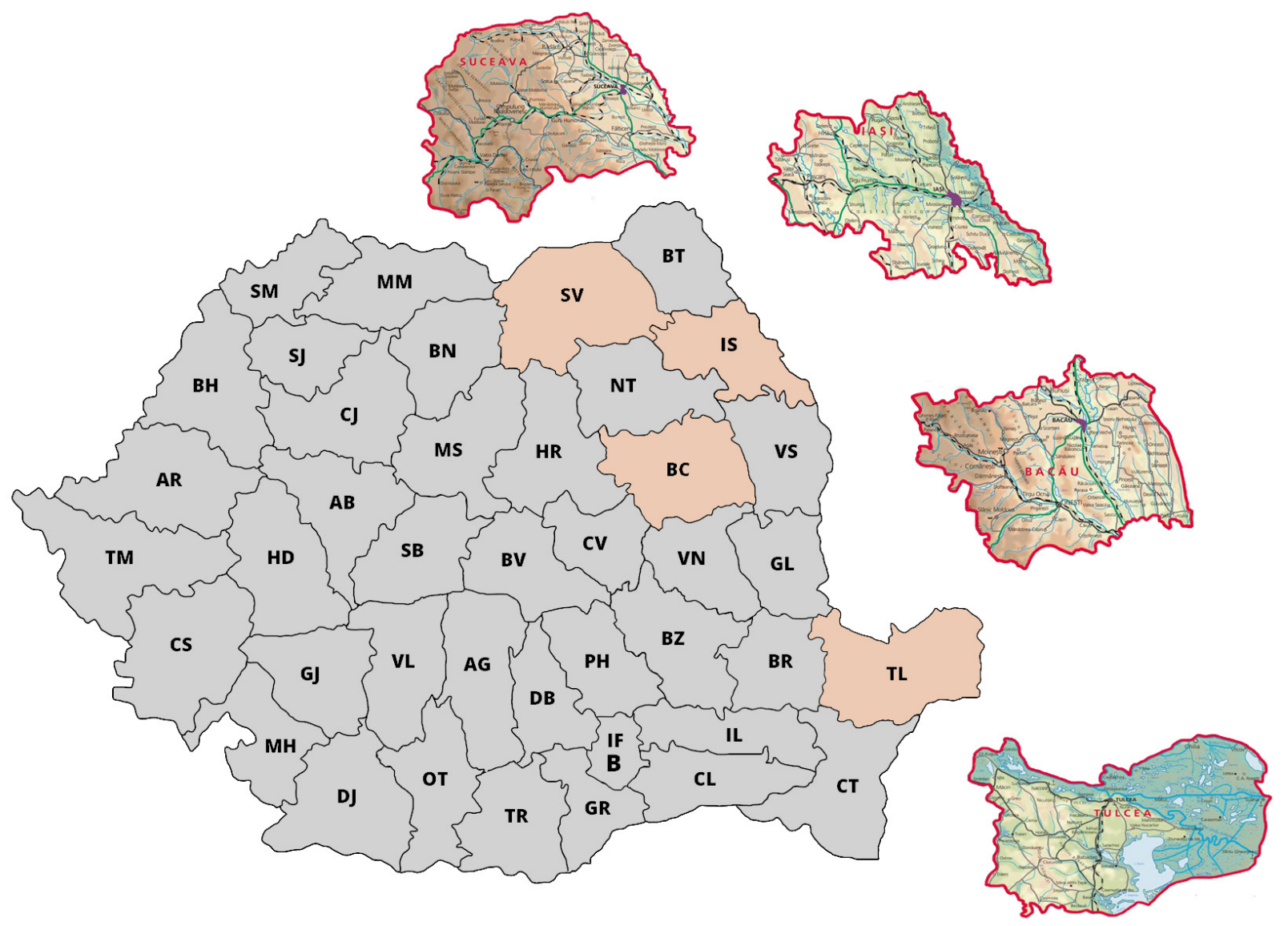

Figure1. Map of sampling and studied areas

dogs, where out of 12 tested dogs, only one had anti-WN antibodies.

Therefore, the WNV seroprevalence in dogs was 5.3 times higher than the WNV seroprevalence in humans in the same areas, suggesting that dogs may be useful sentinel indicators for WNV.

From our knowledge, this is the first attempt to asses WNV seroconversion in dogs in Romania, in which we try to outline the role of dogs as sentinels for virus circulations. Because of the possible cross reactions with members belonging to the same serocomplex, we consider that our results should be further verified using a more specific diagnosis test.

\section{Conclusions}

Based on our serologic surveillance and seropositivity obtained, this preliminary study confirms that either WNV or a very closely related virus is circulating over a wide but not homogenous region of Romania, where outbreaks with WNV were reported both in horses and humans and finally in dogs, which are exposed to virus.
This preliminary study results emphasize the need for further investigation on the potential use of dogs as sentinel indicators for WNV, the potential risk of human exposure and also for the comprehension of the virus epidemiology and circulation.

From our knowledge, this is the first report of West Nile virus seroconversion in dogs in Romania, and due to possible cross-reaction with other viruses belonging to the same serocomplex, the obtained results will be validated by serum neutralization test.

Acknowledgments. This research did not receive any specific grant from funding agencies in the public, commercial, or not-for-profit sectors.

\section{References}

1. Briese T, Bernard KA (2005). West Nile Virus - an Old Virus Learning New Tricks?. J Neurovirol, 11: 469-475.

2. Buckweitz S, Kleiboeker S, Marioni K, Ramos-Vara J, Rottinghaus A, Schwabenton B, Johnson G (2003). Serological, Reverse Transcriptase-Polymerase Chain Reaction, and Immunohistochemical detection of West 
Nile Virus in a Clinically Affected Dog. J Vet Diagn Invest, 15:324-329.

3. Calistri P, Giovannini A, Hubalek Z, Ionescu A, Monaco F, Savini G, Lelli R (2010). Epidemiology of West Nile in Europe and in the Mediterranean basin. Open Virol J, 4:29-37.

4. CNSCBT - Centrul National de Supraveghere și Control al Bolilor Transmisibile - (2012). http://cnscbt.ro/index. php/rapoarte-anuale/546-analiza-evolutiei-bolilortransmisibile-aflate-in-supraveghere-raport-pentruanul-2012.

5. CNSCBT - Centrul National de Supraveghere și Control al Bolilor Transmisibile - (2013). http://cnscbt.ro/index. php/rapoarte-anuale/547-analiza-evolutiei-bolilortransmisibile-aflate-in-supraveghere-raport-pentruanul-2013.

6. CNSCBT - Centrul National de Supraveghere și Control al Bolilor Transmisibile - (2014). http://cnscbt.ro/index. php/rapoarte-anuale/548-analiza-evolutiei-bolilortransmisibile-aflate-in-supraveghere-raport-pentruanul-2014.

7. Lan D, Ji W, Yu D, Chu J, Wang C, Yang Z, Hua X (2011). Serological evidence of West Nile virus in dogs and cats in China. Arch Virol, 156:893-895.

8. Davoust B, Leparc-Goffart I, Demoncheaux JP, Tine R, Diarra M, Trombini G, Mediannikov O, Marié JL, (2014). Serologic Surveillance for West Nile Virus in Dogs, Africa. Emerg Infect Dis. Doi: 10.3201/eid2008.130691.

9. Gamino V, Hofle U, (2013). Pathology and tissue tropism of natural West Nile virus infection in birds: a review. Vet. Res. Doi: 10.1186/1297-9716-44-39.

10. Garcia-Bocanegra I, Arenas-Montes A, Napp S, Jaen-Tellez JA, Fernandez-Morente M, Fernandez-Molera V, Arenas A (2012). Seroprevalence and risk factors associated to West Nile virus in horses from Andalusia, Southern Spain. Vet. Microbiol, 160: 341-346.

11. Garcia-Bocanegra I, Jurado-Tarifa E, Cano-Terriza D, Martinez R, Perez-Marin JE,
12. Lecollinet $S$, (2018). Exposure to West Nile virus and tickborne encephalitis virus in dogs in

13. Spain. Transbound Emerg Dis, 65: 765-772.

14. Gaunt MC, Waldner C, Taylor SM, (2015). Serologic Survey of West Nile Virus in Pet Dogs from Saskatchewan, Canada. Vector Borne Zoonotic Dis, 15:755-758.

15. Hubalek Z, Halouzka J, (1999) West Nile fever - a reemerging mosquitoborne viral disease in Europe. Emerg Infect Dis, 5:643-650.

16. Levy JK, Lappin MR, Glaser AL, Birkenheuer AJ, Anderson TC, Edinboro CH (2011). Prevalence of infectious diseases in cats and dogs rescued following Hurricane Katrina. J Am Vet Med Assoc, 238(3):311- 317.

17. Kile JC, Panella NA, Komar N, Chow CC, MacNeil A, Robbins B, Bunning ML (2005). Serologic survey of cats and dogs during an epidemic of West Nile virus infection in humans. J Am Vet Med Assoc, 226: 1349- 1353.

18. Ludu L, (2010) - Thesis "Epidemiological research on West Nile virus in Romania ",USAMV Iasi, 2010.

19. Ludu (Oslobanu) EL, Mihu-Pintilie A, Anită D, Anita A, Lecollinet S, Savuta G (2014). West Nile virus reemergence in Romania: a serologic survey in host species. Vector Borne Zoonotic Dis, 14(5):330- 337.

20. Maquart M, Dahmani M, Marie J-L, Gravier P, LeparcGoffart I, Davoust B (2016). First serological evidence of West Nile virus in horses and dogs from Corsica Island, France.

21. Vector Borne Zoonotic Dis, 17(4): 275-277.

22. Ozkul A, Yildirim Y, Pinar D, Akcali A, Yilmaz V, Colak D (2006). Serological Evidence of West Nile Virus (WNV) in Mammalian Species in Turkey. Epidemiol. Infect, 134:826-829.

23. Paz S (2015) Climate change impacts on West Nile virus transmission in a global context. Philos Trans R Soc Lond B Biol Sci, 370 (1665): 20130551. 